\title{
低フッ素累代飼育のラットに及ぼす影響
}

とくにフッ素の離乳仔への移行について

鈴 木 隆 男*

概要 : 低フッ素基礎飼料 (F 0.45 ppm) を与えながら F 濃度それぞれ $0,0.5 ， 1 ， 10$ および $50 \mathrm{ppm}$ の飲用群をつくり, Sprague-Dawley 系雌雄ラットを 2 代にわたり飼育して, 体重, 血球数, 血清 ALP, GOT, 出産率, 哺育率を比較した。さらに 0 および10 ppm の 2 レベルは 3 代まで観察を続行した。 また硬組織の F 濃度を最新の Fイオン電極法で測定し, 世代の間, 親仔の間の F 濃度の推移を追求し た。その結果は, 体重の増加の抑制が $50 \mathrm{ppm}$ および第 2 代の $10 \mathrm{ppm}$ 群にみられた以外は血球数, 血 清酵素などについてF投与レベル間に有意の差を認めなかつた。第 1 代雄成育仔の組織 $\mathrm{F}$ 濃度は, 大 腿骨14.1，切歯15.1ppm まで低下したが (市販固形飼料飼育のそれぞれ $3 \%$ よむひ $9 \%$ の低值) その 仔，すなわち第 2 代生育仔との間には有意の差を認めなかつた。世代を重ねても組織濃度が低下しな い原因は, 試作飼料の除F が十分でなく，離乳後飼料より摂取した $\mathrm{F}$ が蓄積して，一定期間後は，ほ ぽ同一水準に達するためと考えられる。F投与群は飲用 $\mathrm{F}$ 濃度に比例して有意の体内蓄積を示すが, 投与 $\mathrm{F} レ$ ベル0 1 ppm の範用では離乳仔の骨濃度は常に 9 10 ppm に止り, 胎盤, 乳腺に生理的 barrier があることを示す。しかし $10 \mathrm{ppm}$ より高レベルでは，仔の硬組織濃度は親の10\%を保持する が，移行した絶対值は投与量に比例して当然高くなり，単なる物理化学的滤過に止まると考えられる。

\section{EFFECTS OF LOW FLUORIDE FEEDING THROUGH SUCCESSIVE GENERATIONS ON RATS}

\section{- With Particular References to the Transfer of Fluoride to Weanlings -}

\section{Takao SUZUKI*}

For the purpose to elucidate the nutritional essentiality or non-essentiality of minute fluoride and also the magnitude of the placental and mammary barrier for fluoride, the experiments of feeding rats defluoridated feed and fluoride water of graded dose through three generations were conducted.

1. The determination of minute fluoride was done with the latest device, the fluoride ion electrode. It was found to be very quick and reliable.

2. The basal diet contained $0.45 \mathrm{ppm} F$ which was as low as one hundredth of commercial rat compressed feed. The graded doses of fluoride water were $0,0.5,1,10$ and $50 \mathrm{ppm}$.

3. The growth was retarded at $50 \mathrm{ppm}$ in both generations and at $10 \mathrm{ppm}$ in males of the second generation.

4. No significant difference was found in blood examinations between the dose levels,

* 東京歯科大学大学院歯学研究科衛生学専攻（指導：上田喜一教授）

Department of Hygiene, Tokyo Dental College

本研究は一部昭和 43 年度文部省科学研究費 (高江洲義矩奖励研究) の補助による。

昭和 44 年 2 月 7 日受付 
including erythrocytes and leucocytes count, hematocrit, ALP and GOT.

5. The adult male rats of the first generation of low fluoride feeding contained $14.1 \mathrm{ppm}$ $\mathrm{F}$ in femurs and $15.1 \mathrm{ppm} \mathrm{F}$ in incisors, decreasing to only three per cent and nine per cent resp. of that on commercial rat compressed feed.

6. The adult male rats of the second generation showed no significant decrease of hard tissue fluoride compared with that of the first generation. It may be attributed to the accumulation from not so completely defluoridated feed through the growth.

7. The mandible of weanlings of the second generation contained fluoride as low as 8.7 ppm $\mathrm{F}$, equivalent to 40 per cent of the mother rats.

8. The mandible of weanlings of the third generation contained $7.5 \mathrm{ppm} \mathrm{F}$, equivalent to 50 erpcent of the dams.

9. At all dose levels through $0,0.5$, to $1 \mathrm{ppm}$ of fluoride, the bones of weanlings were keeping a constant level of fluoride around $10 \mathrm{ppm}$, indicating an active physiological barrier in placenta and mammary glands.

10. At 10 and $50 \mathrm{ppm}$ of dose level, the reduction of fluoride in hard tissues of weanlings showed a constant ratio around 10 per cent of that of dams, suggesting a passive physicochemical filtration. The absolute level in tissues of pups was consequently increased.

11. At higher dose level, the pups of the second generation contained significantly higher fluoride in hard tisses compared with that of the first generation.

\section{はしがき}

高濃度フッ素の影響に関しては古くから多数の 業績があるが，逆に超低濃度のフッ素が生理的に 意義があるか否かについては研究発表は非常に少 ない。その原因は超低フッ素の作製が困難である からと考える。

フッ素が必須栄養素であるかとの疑問に関して は古くSharpless と McCollum ${ }^{11}$ (1933)の実験に 始り, 最近の Maurer ${ }^{2)}$ (1957) らの研究まで数編 の論文 3/4) 5/6) があるが, 古いものはフッ素測定值 が信頼できず，新しい研究も未だ観察項目が少く 結論には達していない。

著者はこの点に興味を持ち, 最新のフッ素分析 法を応用して新知見を求めようと考え, 本実験に 着手した。

従来の成績によると, 硬組織に蓄積したフッ素 は拔け難く，低フッ素飼育で世代を重ねてようや く低下しうるとの報告が多いから，著者もまた累 代繁殖試験を行うことが必要となつた。この事は 必然的に最も興味ある胎仔へのフッ素移行問 題71819)10) をとりあげることとなり、胎盤, 乳腺の フッ素に対する障壁（barrier）の意義も研究する こととなつた。

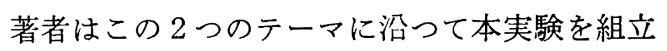
てた。

まず，なるべく簡易な方法で飼料の脱フッ素精 製を行い市販固形飼料の $1 / 100$ の低フッ素飼料 (0. $45 \mathrm{ppm})$ を得てこれを基礎飼料としてラットを 3 代にわたつて飼青し, 種々の生理值, 硬組織一 のフッ素蓄積を測定した。

この際, 最新のフッ素電極による微量定量法を 採用したので，1 日30検体以上を完全に処理する ことができ，また従来の比色法では到達し得ない 低フッ素でしかも微量試料すなわち低フッ素食離 乳仔歯牙なども十分精確に 分析し得たので，先 人の業績に対して多少の知見を加え得たと信じ る。

また低フッ素 3 代飼育の後, 実験的カリエスの 罹患度に及ぼす影響を実験したが, その成績は次 報に述べることとする。

\section{実験方法}


市販の固形飼料オリエンタル N.M. で, 当教室で 3 代飼育した生後約 4 カ 月の Sprague-Dawley 系ラット, 体 重雄400 500 g, 雌 250 300 g のもの を親として出発した。

雄20匹, 雌40匹を 1 週間後述の低フ ッ素 $(\mathrm{F})$ 基礎飼料で飼育後, 交配, 出 産させて得た仔を第 1 代の子孫として 実験した。

さらに各フッ素 $(\mathrm{F})$ 濃度群ごとに第 2 代第 3 代の子孫を出産せしめた。

\section{2) 基礎飼料}

市販固形飼料 ${ }^{11}$ は約 $45 \mathrm{ppm}$ の多量 のFを含有するので(表 1 ), 自家製低 $\mathrm{F}$ 基礎飼料を調製した。飯塚 ${ }^{121}$ による 処方を改変した組成で表 1 の様にドラ イミルクを多くして塩類混合物を比較的少量にし た。これは塩類混合物からの多量のFが混入する のを防ぐためである。

分析の結果 $\mathrm{F}$ 量は $0.45 \mathrm{ppm}$ であつた。表 1 に 示すよらにオリエンタル N.M. と比べて栄養構 成分はほぼ同様であるが，F 量は $1 / 100$ に減少して いる。

第 2 代の実験では, 天然高 $\mathrm{F}$ 食としてのフィシ ユミールと $\mathrm{F}$ 飲料水との硬組織 $\mathrm{F}$ 沈着率を比較す る計画 ${ }^{35)}$ を加えたので, フィシュミール群の飼料 を次の如く調製した。

小麦粉 53, ドライミルク 25, フィシュミール 20 , 塩類混合物 2 , 総合ビタミン液 $0.2 \mathrm{ml} / 100 \mathrm{~g}$, 分析の結果フィシュミール中の $\mathrm{F}$ 量は約 $90 \sim 100$ $\mu \mathrm{g} / \mathrm{g}$ であつたのでフィシュミール飼料の F 量は 20ppm となるように作製した。

\section{3）混合塩類の精製}

なるべく F 量が低減することが望ましいので, $\mathrm{F}$ 量の多い塩類混合物を Sharpless ${ }^{11}$ や McClendon $^{13)}$ らの方法を参考にして次の 如き簡単な方法 で精製を行なつた。

$\mathrm{NaCl}$ は稀塩酸に溶かし蒸留水を加えガラス玉 を入れて, 加熱濃縮をくり返した。

$\mathrm{CaCO}_{3}$ は Magregian ${ }^{14)}$ の方法を参考にして精 製した。 $\mathrm{KH}_{2} \mathrm{PO}_{4}$ は蒸留水に溶かしアルコール
表 1 低フツ素飼料の組成

\begin{tabular}{|c|c|c|c|c|c|c|c|c|}
\hline 組 成 & 百分率( & $\begin{array}{l}\text { (Ca l) } \\
\text { 力口 } 1 \text { - }\end{array}$ & 蛋白質(g) & 脂 & 質(乌) & 糟 & 質(g) & $\begin{array}{l}F \quad \text { 量 } \\
(\mathrm{ppm})\end{array}$ \\
\hline 小 麦 & 57 & 2029 & 4. 7 & & 0.5 & & 4. 3 & a 30 \\
\hline カゼイン & 15 & 553 & 12. 6 & & 0.2 & & 02 & 0.33 \\
\hline トラィミルク & 25 & 1168 & 4. 5 & & 4. 9 & & 1. 4 & 0.7 \\
\hline 混合坮 & 3 & & & & & & & 2. 2 \\
\hline 計 & 100 & 375 & 21.8 & & 5.6 & & 5. 9 & 0.45 \\
\hline $\begin{array}{l}\text { 市肘固形 } \\
\text { 飼料オ灶 } \\
\text { ンタルNM }\end{array}$ & & 360 & 265 & & 61 & & 5. 0 & 45 \\
\hline
\end{tabular}

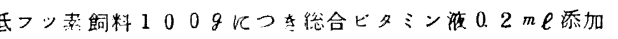

表 2 混合塩組成

$\begin{array}{lr}\mathrm{NaCl}_{\mathrm{K}} & 13 \\ \mathrm{Ka} \mathrm{CO}_{2} \mathrm{PO}_{4} & 39 \\ \mathrm{MgSO}_{4} & 35 \\ \mathrm{Fe} \mathrm{PO} & 10 \\ \mathrm{~K}_{2} \mathrm{Al}_{2}\left(\mathrm{SO}_{4} \cdot 12 \mathrm{H}_{2} \mathrm{O}\right. & 1\end{array}$

M c Col1um 混合塩件 51 よびJones-Foster 湿 合塩処方改育

を加えて再結晶させる操作を数回くり返した。 $\mathrm{MgSO}_{4}, \mathrm{FePO}_{4}$ は蒸留水から再結晶させ硫酸に溶 かした後, 乾燥後赤熱した。 $\mathrm{K}_{2} \mathrm{Al}_{2}\left(\mathrm{SO}_{4}\right)_{2} \cdot 12 \mathrm{H}_{2} \mathrm{O}$ は蒸留水で数回再結晶した。

\section{4) 実験計画 (図 1)}

第 1 代の離乳仔を 1 群雄 5 匹, 雌10匹とし 0 (蒸 溜水)，0.5，1，10，50 ppm のF濃度を有する $\mathrm{NaF}$ 溶液を自由に飲ませた。投与後 65 日で各群 雄雌を $1: 2$ で同居, 交配させした。交配の確認 は腟脂こう形成および塗沫標本による精子証明 ${ }^{15}$ によった。

投与後 75 日で雄全部と, 各群未妊娠雌ラット 3 匹を心臟穿刺採血して屠殺した。

第 2 代は各群雄 6 匹， 0 と $10 \mathrm{ppm} \quad \mathrm{F}$ 群雌のみ 


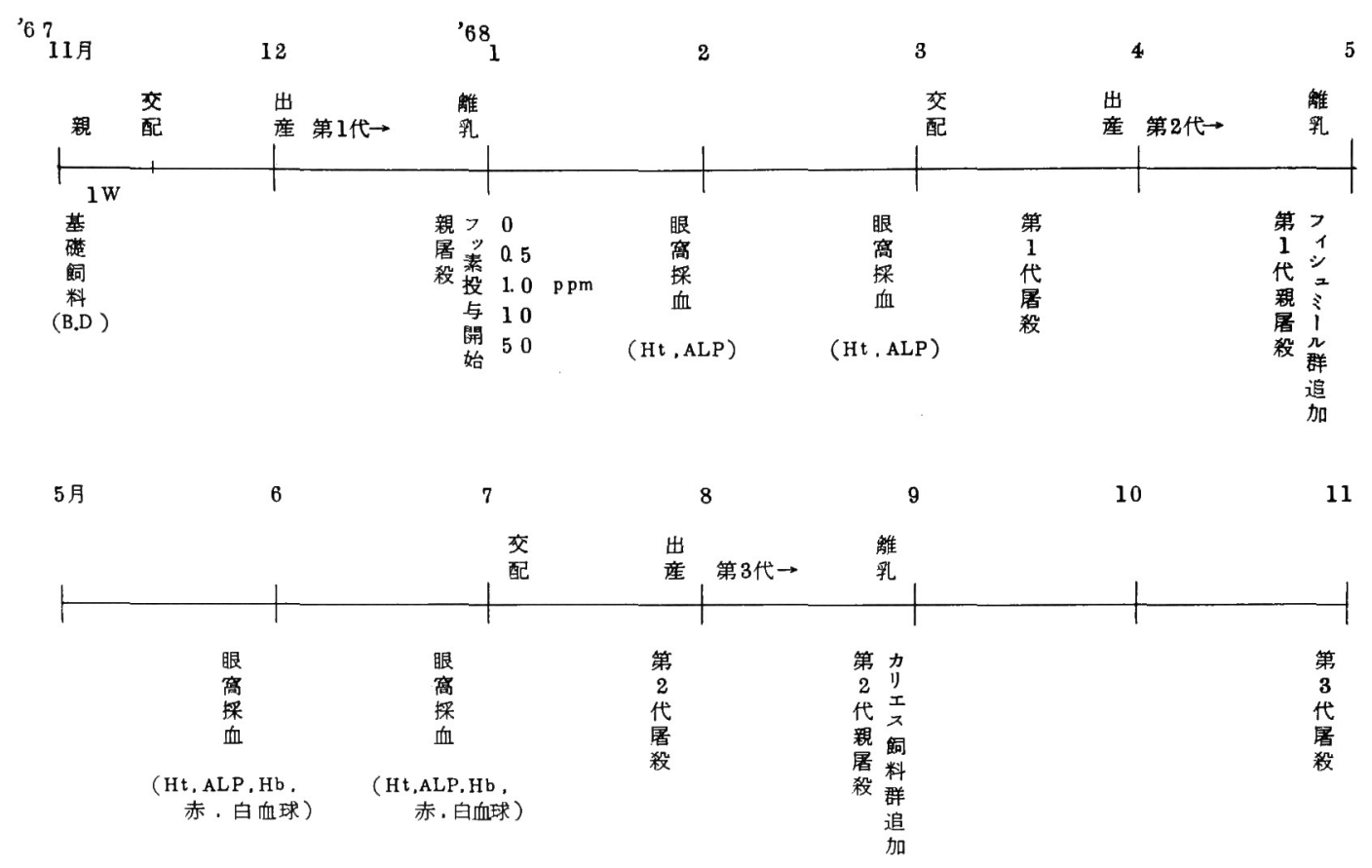

図 1 実戨計画

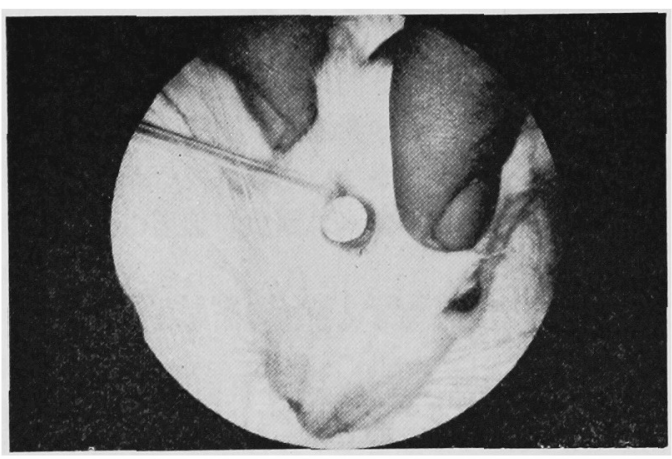

図 2 眼窩静脈叢採血, 毛細管老插入し ているところ

さらに 6 匹を加えてそれぞれ第 1 代と同様に飼䏍 した。第 2 代からは天然高 $\mathrm{F}$ 飼料としてのフィシ ユミール群を追加した。投与後 70 日で $0 \mathrm{ppm}$ 群 と10ppm 群をそれぞれ同居，交配させた。投与 後90日で雄を屠殺した。各群の離乳親と任意に選 んだ離乳仔を屠殺し親から仔へのF移行を知るた め分析に供した。

投与後 1 ケ月， 2 ケ月目にラットの眼窩静脈叢 から採血し，ヘマトクリット值 $(\mathrm{Ht})$, アルカリフ オスファターゼ值(ALP) を測定し, 第 2 代では赤,

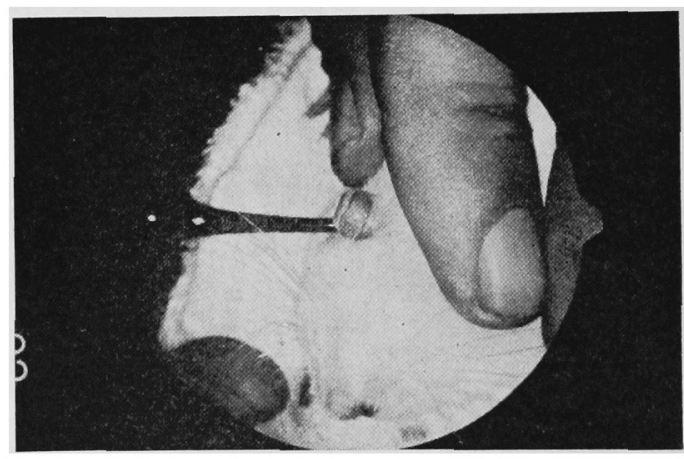

図 3 眼窩静脈叢採血。採血（約 $1 \mathrm{ml}$ ) しているところ

白血球，ヘモグロビンを追加し，時間的変化を観 察した。

採血の方法 ${ }^{16)}$ はラッテをエーテルで麻酔し固定 器にのせ, 上下瞼を引つぱり眼球を突出させ, 眼 球と下眼瞼の間から，ヘパリン処理済みの尖端を 鋭がらした毛細管ガラス（内径 1.4〜6 mm 長さ $75 \mathrm{~mm}$ ）で斜後方にさしこみ，蝶形骨に達して， 少し戻すと血液が毛細管を上景してくる。体重 $150 \mathrm{~g}$ のもので $1 \mathrm{ml}, 250 \mathrm{~g}$ の もの゙ $2 \mathrm{ml}$ を貧血 その他の後障害なしに，1ケ月1度採血できた。 

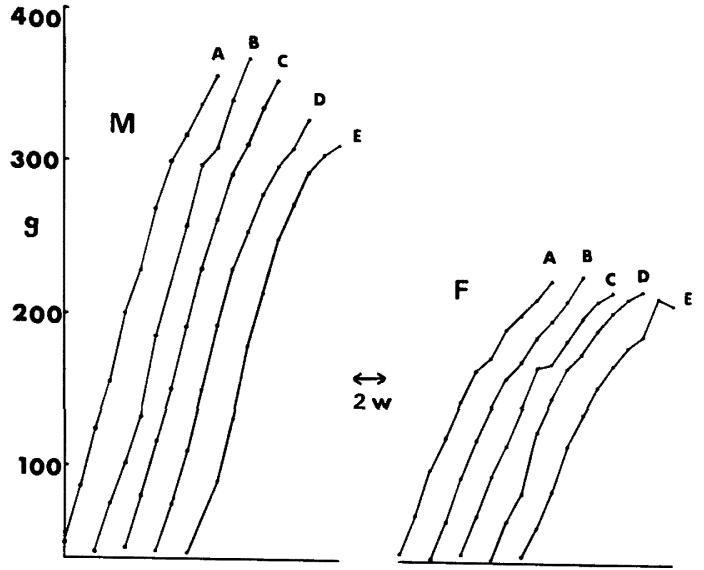

図 4 第 1 代体重增加曲線
A B.D. +0 ppm
B B.D. $+0.5 \mathrm{ppm}$
C B.D. $+1 \mathrm{ppm}$
E B.D. +50 ppm
$\mathrm{M}$ (§) 1 群 5 匹
F (우) 1 群10匹

屠殺時は心臟穿刺採血で GOT を測定した。ALP は0.05 ml の微量血清で測定できるヤトロン社製 の Kind-King 改良法キットを用いた。GOT はヤ トロン社製のライトマンーフランケル改良法キッ トを用いた。

飼料, 飲水量は 2 日に 1 度, 体重は 1 週 1 度測 定し, 一般状態, 切歯エナメル質表面変化, 出産 状況を観察した。

\section{5) F 定量法}

飼料の分析には水蒸気蒸留一SPADNS 法 ${ }^{17)}$ と Alizalin Complexan 法 $^{18)}$ (以下 ALC と略) で比較 定量し, 必要ある時は当教室高江洲の微量抎散 一ALC 法 ${ }^{19)}$ を応用した。ラット硬組織の F 分析 は当教室近藤ら ${ }^{299}$ が発表した，Fイオン電極法で 測定した。Fイオン電極法の試料前処理として 最初に Singer-Armstrong ${ }^{21}$ に従い灰化を行って 定量したが，低 $\mathrm{F}$ 試料とくに離乳仔の硬組織の $\mathrm{F}$ 值が従来の定量法による測定值と著しく異る高值 を得たので, 次に $\mathrm{McCann}^{22)}{ }^{23)}$ の方法に準じて 灰化を省略して分析を行つた。

すなわち $60 \mathrm{mesh}$ に粉砕, 脱脂, 乾燥 $\left(100^{\circ} \mathrm{C}\right.$ 3 時間）した試料を小型スチロール共栓容器に, 10 20 mg 採取し， $0.5 \mathrm{M}$ 過クロール酸 $1 \mathrm{ml}$ で 溶解させ, 必要あれば 1 時間時々振とうして放置 後 $0.50 \mathrm{M}$ クエン酸ナトリウム $4 \mathrm{ml}$ を加え総計 5

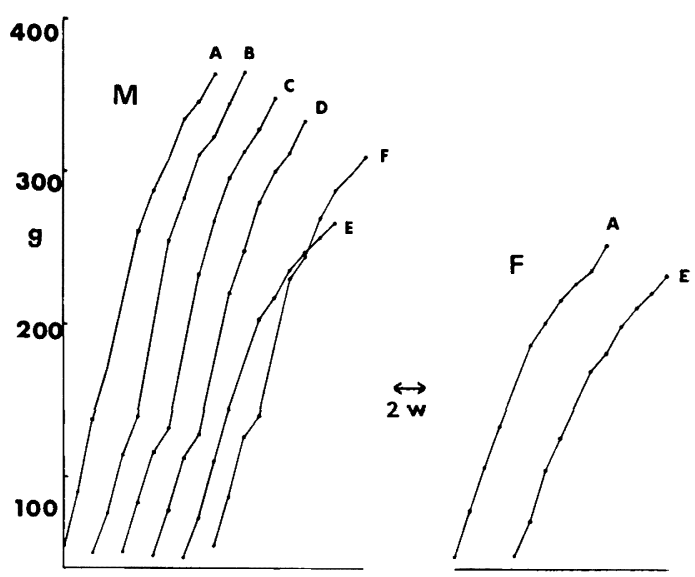

図 5 第 2 代体重增加曲線
A B.D. +0 ppm
C B.D. $+0.5 \mathrm{ppm}$
E B.D. $+10 \mathrm{ppm}$
B フイシュミール
$\mathrm{M}($ 今) 1 群 6 几
D B.D. $+1 \mathrm{ppm}$
F B.D. +50 ppm
$\mathrm{F}$ (우) 1 群 6 匹

$\mathrm{ml}$ とし，あらかじめ $\mathrm{F}$ 標準液で調整ずみの $\mathrm{F} イ$ オン電極メーターで測定した。標準溶液の作製は $0.5 \mathrm{M}$ 過クロール酸 $100 \mathrm{ml}, 1 \mathrm{M}$ クエン酸ナトリ ウム $200 \mathrm{ml} に 0.05,0.1,0.5,1,10 \mathrm{~F} \mu \mathrm{g} / \mathrm{ml}$ と なるように $\mathrm{NaF}$ を加え蒸留水で $500 \mathrm{ml}$ とした。

\section{6) 有意差検定}

本実験では各群の動物数が $4 \sim 10$ 例と小数でし かも，酵素活性，F含有量など母集団が正規分布を するかどうか不明な測定項目があるので，母集団 の分散に無関倸な検定法(non-parametric) である Wilcoxon ${ }^{25}$ の順位統計法 (Rank method) を用い て有意差検定をした。本法は通常比較する両群の 個体数が同数の場合しか発表されていないので, 本実験のように例数の不一致の実験を含む場合に は不便であつたが，幸にオランダの Wabeke と Eeden $^{24)}$ の拡張した検定表を入手し得たので全面 的に本法を採用した。

Wilcoxon の順位検定法は計算が 極めて簡単で しかも例数の少い時はより信頼し得るとされてい る。試みに体重増加度（表 3) について通常の繁 雑な分散を用いる $\mathrm{t}$-検定と Wilcoxon 法とを併用 してみたが有意差の判定は全く一致した成績を得 た。 
表 3 体重增 加

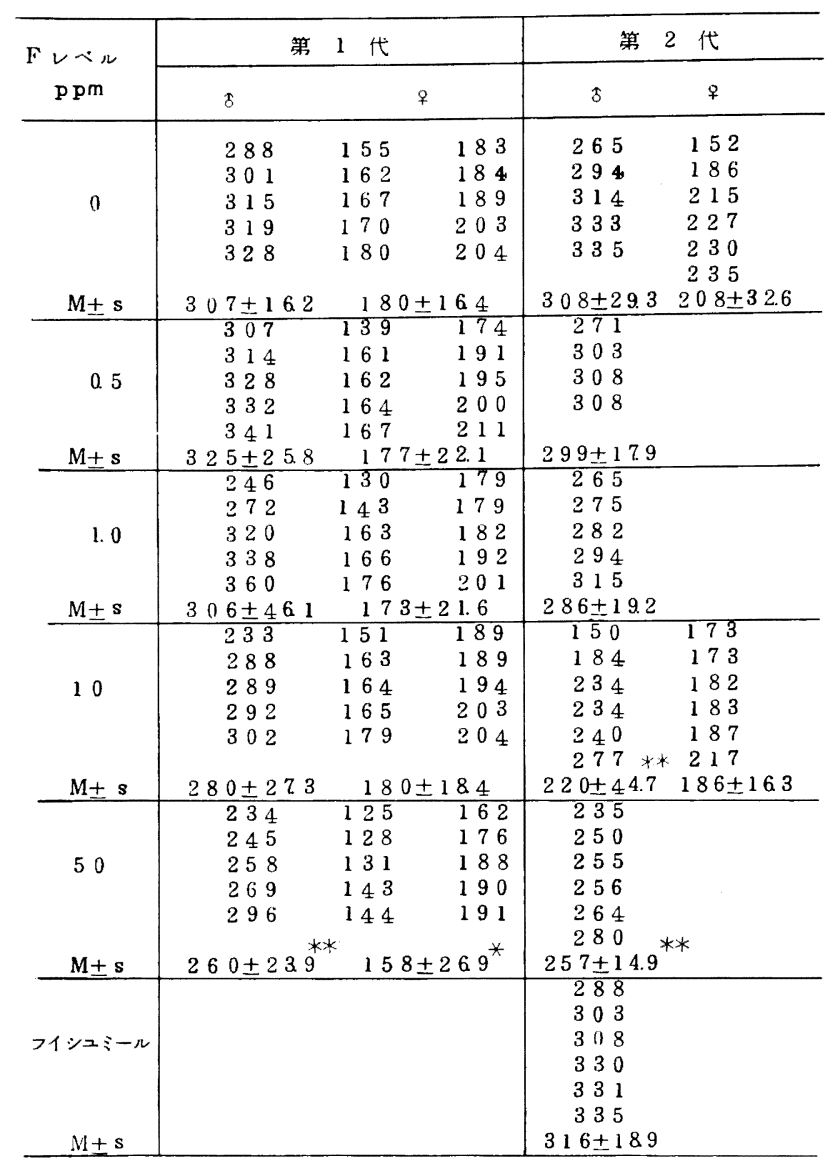

生1. 各レべの数值は10週目体重から初体重をひいた值を示す。 $2 \mathrm{M}$ 平均 $\mathrm{s}$ 平均值の僄本分散

30 ppmレべと比して $*(<0.05)$ 較し $(<0.01)$ 亿有意の差を認めた

\section{実 験 成 績}

\section{1) 体 重}

体重増加曲線は第 1 代の仔（図 4 ）第 2 代の仔 (図 5 ) は概して平行して上昇しているが，最終体 重は, F 10 および $50 \mathrm{ppm}$ 群では劣るように見え る。しかし各個体の体重増加量を比較すると表 3 に示すように, F $50 \mathrm{ppm}$ 群は第 1 代，第 2 代と も $0 \mathrm{ppm}$ 群（基礎飼料群）との間に有意差があ つたが, $10 \mathrm{ppm}$ では第 2 代の雄のみが明かに劣 る成績となった。

\section{2）ラット出産状況（表 4)}

母体当り平均仔数は, 投与 $\mathrm{F}$ レベル間で有意の
差は認められなかつた。

3）血液所見（表6，7）

a) ヘマトクリット値 $(\mathrm{Ht})$

第 1 代，第 2 代とも成長に従つて増加している が，1 ケ帛 2 ケ月の間の増加がより著しい。F 投与各群の間には有意差はない。

b) 赤血球数, 白血球数

へモグロビン量も成長に伴って増加の傾向があ るが, F濃度各群間には有意な差はなかつた。

c）アルカリフォスファターゼ值 (ALP)

この值は逆に成長と共に低下している。

各個体值の変動が甚しいので平均值の間に有意 差は認められなかつた。僅かに第 2 代成育仔(表 
表 4 ラット出産状 況

\begin{tabular}{|c|c|c|c|c|}
\hline & \begin{tabular}{|c}
$F \cup \sim ル$ \\
$(\mathrm{ppm})$
\end{tabular} & 総母体数 & 紿 生 仔数 & 母休別平均仔数 \\
\hline 漞 & & 23 & 174 & 7. 6 \\
\hline \multicolumn{5}{|l|}{ （第，1代） } \\
\hline & 0 & 5 & 29 & 5.8 \\
\hline & 0.5 & 4 & 21 & 5. 0 \\
\hline & 1. 0 & 7 & 64 & 9.1 \\
\hline & 10 & 6 & 43 & 7. 2 \\
\hline & 50 & 3 & 27 & 9. 0 \\
\hline \multicolumn{5}{|l|}{ (第 2 代) } \\
\hline & 0 & 5 & 39 & 7. 8 \\
\hline & 10 & 6 & 33 & 5.6 \\
\hline
\end{tabular}

注：低 $\mathrm{F}$ 基整铜料 2 ケ月

表 5 ラット歯牙フッ素症出現時期

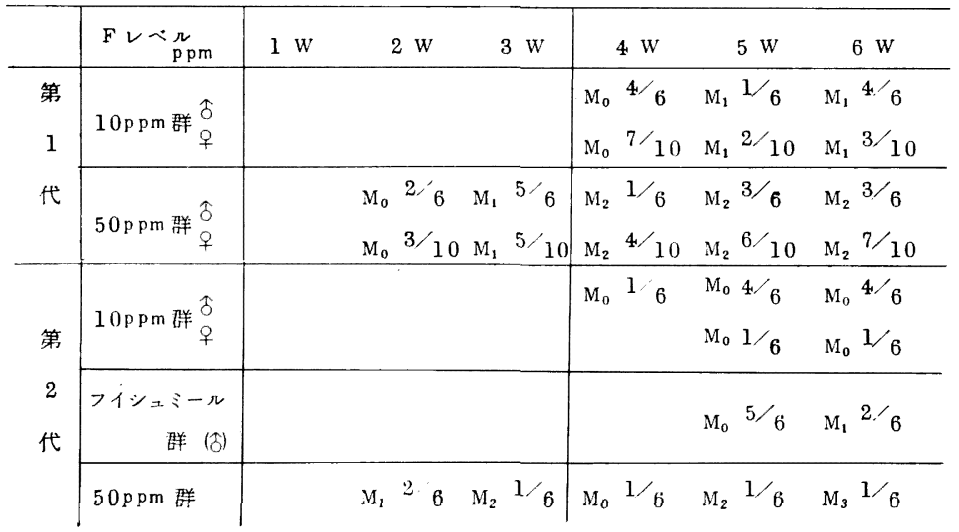

判定基準 $\mathrm{M}_{0}$ 僅か儿裉色

$M_{1}$ 明らかに白色を帯びてくる、切端、周用部のみ

$\mathrm{M}_{2}$ 全体に白色を带びる

$M_{3}$ チョーク様(大理石様) 変化

表現方法総匹数中強度に橉牙変化を起した匹数 
表 6 第 1 代検查成 縜

\begin{tabular}{|c|c|c|c|c|c|c|c|c|}
\hline \multicolumn{2}{|c|}{$\begin{array}{l}F \cup \sim ゚ \\
\quad(p p m)\end{array}$} & \multicolumn{2}{|c|}{$\begin{array}{c}\text { へマトクリット值 } \\
(\%) \\
\end{array}$} & \multicolumn{3}{|c|}{$\begin{array}{c}\text { アルカリフォスファターセ値 } \\
\text { (K.A. 単位) }\end{array}$} & \multicolumn{2}{|c|}{$\begin{array}{c}\text { 贜器重鯂体重比 } \\
(\%) \\
\end{array}$} \\
\hline & & I & II & I & II & III & 肝 & 腎 \\
\hline \multirow{2}{*}{ B.D. +0} & $\hat{\delta}$ & 41.8 & 4.5 & 455 & 34.1 & 29.2 & 302 & 0.677 \\
\hline & 우 & & & & & 235 & 2.74 & 0.627 \\
\hline \multirow{2}{*}{0.5} & $\hat{\delta}$ & 42.8 & 464 & 40.4 & 36 & 24.6 & 2.68 & 0.651 \\
\hline & 우 & & & & & 17.7 & 372 & 0.738 \\
\hline \multirow{2}{*}{ 1. 0} & $\hat{\delta}$ & 42.0 & 49.1 & 45.3 & 26 & 20.5 & 2.76 & 0.558 \\
\hline & 우 & & & & & 163 & 2.90 & 0.673 \\
\hline \multirow{2}{*}{10} & $\hat{\delta}$ & 44.8 & 50.6 & 39.8 & 28 & 25.7 & 331 & 0.580 \\
\hline & \& & & & & & 267 & 348 & 0.609 \\
\hline \multirow{2}{*}{50} & 令 & 4.1 .8 & 4.9 .3 & 38.4 & 30.6 & 30 & 2.92 & 0.593 \\
\hline & 우 & & & & & 258 & 2.91 & 0.524 \\
\hline
\end{tabular}
合 5 匹
우 3 匹平均值
I：投与後 30 日
III : " 60 日
III : "75日

表 7 第 2 代 検 査 成 績

\begin{tabular}{|c|c|c|c|c|c|c|c|c|c|c|c|}
\hline \multirow{2}{*}{$\begin{array}{l}\text { Fレベル } \\
(\mathbf{p p m})\end{array}$} & \multicolumn{3}{|c|}{$\begin{array}{c}\text { ーマトクリット㑑 } \\
\text { (\%) }\end{array}$} & \multicolumn{2}{|c|}{ 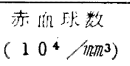 } & \multicolumn{2}{|c|}{$\begin{array}{l}\text { 白血球数 } \\
\left(\begin{array}{lll}1 & 0 & 2\end{array} \mathrm{mon}^{3}\right)\end{array}$} & \multicolumn{2}{|c|}{$\begin{array}{l}\text { へモクロロビン } \\
(g / d l)\end{array}$} & \multirow{2}{*}{$\begin{array}{l}\text { A LP 值 } \\
\text { KA } \\
\text { 单位) }\end{array}$} & \multirow{2}{*}{$\begin{array}{l}\text { OOT值 } \\
(\text { カ } \\
\text { 些位) }\end{array}$} \\
\hline & I & II & III & I & II & I & II & I & III & & \\
\hline 0 & 37.3 & 462 & 476 & 501.8 & 584.4 & 968 & 996 & 11.4 & 14.5 & 13.7 & 72.0 \\
\hline 0.5 & 40 & 423 & 52.0 & 5424 & 5982 & 83.8 & 82.4 & 12.3 & 156 & 14.0 & 670 \\
\hline 1.0 & 39 & 468 & 50.2 & 5331.8 & 6008 & 760 & 81.2 & 12.4 & 15.0 & 11.2 & 59.8 \\
\hline 10 & 38 & 45.8 & 49.8 & 5054 & 6370 & 82.4 & 91.6 & 11.7 & 150 & 163 & 684 \\
\hline 50 & 40 & 45.9 & 50.0 & 510.6 & 651.6 & 838 & 968 & 12.9 & 163 & 18.3 & 59.2 \\
\hline フイシュミ一ー & & & 480 & & & & & & 14.5 & 11.4 & 65.5 \\
\hline
\end{tabular}

(珄) I：投与啳1ヶ月

II : " 2 年月

注：1群 5 匹の平均值

III : " 3 ケ月 
表 8 離乳親の血漿酵素活性

\begin{tabular}{|c|c|c|c|c|c|c|c|}
\hline \multirow{2}{*}{$\begin{array}{l}F \text { レデル } \\
\text { ppm }\end{array}$} & \multicolumn{3}{|c|}{ 第 1 代 } & \multicolumn{3}{|c|}{ 第 2 代 } & \multirow[b]{2}{*}{$\begin{array}{l}\text { 体重 } \\
(\mathrm{g})\end{array}$} \\
\hline & $\begin{array}{l}\text { A L P } \\
\text { ( } K-A \\
\text { 単位 ) }\end{array}$ & $\begin{array}{l}\text { GOT } \\
\text { ( Ka rmen } \\
\text { 单位) }\end{array}$ & $\begin{array}{l}\text { 体重 } \\
\text { (g) }\end{array}$ & $\begin{array}{l}A \text { L P } \\
(K-A \\
\text { 単位) }\end{array}$ & $\begin{array}{l}\text { GOT } \\
\text { (Karmen } \\
\text { 単位) }\end{array}$ & $\begin{array}{l}H t \\
(\infty)\end{array}$ & \\
\hline 0 & 30.2 & 106 & 255 & 378 & 69 & 47.5 & 278 \\
\hline 0.5 & 278 & 89 & 271 & & & & \\
\hline 1 & 20.9 & 104 & 246 & & & & \\
\hline 10 & 27.7 & 102 & 257 & 39.0 & 98 & 430 & 256 \\
\hline 50 & 20.8 & 93 & 222 & & & & \\
\hline
\end{tabular}

$\begin{array}{ll}\text { 第 } 1 \text { 代 } & 3 \sim 4 匹 \\ \text { 第 } 2 \text { 代 } & 5 \sim 6 \text { 匹 }\end{array}$ の平均值

表 9 離乳時ラット硬組織 $\mathrm{F}$ 量（親仔の比較）

a)オリエンタルNM固形飼料飼育

\begin{tabular}{|c|c|c|c|c|}
\hline & & 下顎 骨 & 大腿盄 & 菌 ⿹ $^{\text {米 }}$ \\
\hline \multirow{3}{*}{$\begin{array}{l}\text { 姙 娠 } \\
20 \text { 日(出産 } 2\end{array}$} & 1 & 405 & 385 & 147 \\
\hline & 2 & 430 & 491 & 172 \\
\hline & 3 & 350 & 391 & 184 \\
\hline 日前）屠殺 & 平均 & 395 & 422 & 167 \\
\hline \multirow[t]{5}{*}{ 蜼 乳 漞 } & 1 & 497 & 4.77 & 226 \\
\hline & 2 & 4. 94 & 449 & 217 \\
\hline & 3 & 532 & 450 & 227 \\
\hline & 4 & 410 & 423 & 167 \\
\hline & 平均 & 483 & 450 & 209 \\
\hline \multirow[t]{6}{*}{ 蜼 乳 仔 } & 1 & 168 & 187 & 16.6 \\
\hline & 2 & 24.7 & 17.5 & 17. \\
\hline & 3 & 21.0 & 21.0 & 16.8 \\
\hline & 4 & 23.6 & 22.8 & 17.9 \\
\hline & 5 & 560 & 61.0 & 26.1 \\
\hline & 平均 & 284 & 282 & 189 \\
\hline
\end{tabular}

* 右側

*米䣯切蒾 2 本

$\mathrm{F}$ 浱度：乾燥重量当 $b \mathrm{p} \mathrm{pm}$ 
表 10 離乳時ラット硬組織 $\mathrm{F}$ 量（親仔の比校）

b) 低 $\mathrm{F}$ 飼育 2 ケ月の親と仔

\begin{tabular}{|c|c|c|c|c|c|c|c|c|}
\hline & 動物番号 & 顎 & t & 大 & 腿 & 骨 & 歯 & 牙 \\
\hline & Fa 1 & 25 & 58 & & 25 & 1 & & 41 \\
\hline 第 & 2 & 3 & 00 & & 26 & & & 47 \\
\hline 0 & 3 & 30 & 07 & & 25 & 6 & & $4^{3}$ \\
\hline 代 & 4 & 30 & 03 & & 26 & 5 & & 45 \\
\hline 離 & 5 & 30 & 02 & & 25 & & & 47 \\
\hline 乳 & 6 & 26 & 68 & & 6 & & & 47 \\
\hline \multirow[t]{3}{*}{ 親 } & 7 & 28 & 89 & & 26 & 0 & & 51 \\
\hline & 8 & 2.7 & 77 & & 6 & 6 & & 39 \\
\hline & 平均 & 28 & 88 & & 26 & & & 45 \\
\hline
\end{tabular}

\begin{tabular}{|c|c|c|c|c|c|c|c|c|}
\hline & 動物番号 & 䫑 & 骨 & 大 & 腿 & 骨 & 歯 & 牙 \\
\hline & Ma 1 & 19 & 7 & & 8 & & & 57 \\
\hline 第 & 2 & 11. & & & 8 & & & 62 \\
\hline 1 & 3 & 9 & 2 & & 9. & & & 5.4 \\
\hline 代 & 4 & 9. & 6 & & 6 & & & 64 \\
\hline 離 & 5 & 9. & 7 & & 8 & & & 62 \\
\hline 乳 & 6 & 9 & 1 & & 8 & & & 58 \\
\hline \multirow[t]{4}{*}{ 仔 } & 7 & 10. & 9 & & 8 & & & 7. 4 \\
\hline & 8 & 12. & & & 2 & & & 64 \\
\hline & 9 & 9. & 1 & & 8 & & & 6.2 \\
\hline & 平均 & 10 & 3 & & 8 & & & 62 \\
\hline
\end{tabular}

$\mathrm{F}$ 溜度: 乾燥重量当 $b \mathrm{ppm}$

7 ）の中で最低值を示した $1 \mathrm{ppm}$ 群と, 最高值 $50 \mathrm{ppm}$ 群との間に $5 \%$ の危険率で有意差を認め ただけである。表 8 に示した離乳親の各群間にも 有意差はなかつた。

d) トランスアミナーゼ値 (GOT)

血液量の関係で，GPT を省略し，GOT のみ を行つた。第 1 代の仔についても分析したのであ るがガラス製注射筒を用いたため溶血しやすく， その影響のため 200 以上の異常高値を得たので測 定成績を捨てることにした。第 2 代の仔からはへ パリンでうる扔したジンタン社製のプラスティッ ク注射筒を用いたので溶血による障害を防ぎ得 た。

有意差検定で第 2 代の最低值 (1 ppm 群) と対 照（ $0 \mathrm{ppm}$ 群）の間に有意差が認められた。（P $<0.05)$, 第 2 代の $1 \mathrm{ppm}$ 群が GOT, ALP が共 に最低值であつたのは偶然であるかどうかは他の 項目のデータと併せ考える必要がある。

\section{4) 臟器重量体重比}

第 1 代の仔の雌の腎に異常低值が認められるが 検定により有意差を証明できなかつた。（表 6 ）

\section{5）迷牙フッ素症}

著者は表 5 に記載したような判定基準に従つて 追跡観察を行つたところ, 第 1 代のF $10 \mathrm{ppm}$ 群 では第 4 週から, $50 \mathrm{ppm}$ 群は第 2 週で歯牙表面に 褪色がみられるようになつた。第 2 代では $10 \mathrm{ppm}$ およびフィシュミール群（天然フッ素20ppm）は $4 \sim 5$ 週から褪色が始り, 50 ppm は 2 週からす でに帯白色となり，6週では 1 例にチョーク様変 性をみた。

著者の観察によると, ラット歯牙表層の変化は 持続的に一定でなく，実験期間中においてその表 層の様相の変動が認められた。このことはラット 下顎切歯に抢いて特有な現象であつた。

ラットの歯牙フッ素症については, すでにカラ 一写真 ${ }^{26)}$ を発表してあるので今回は省略する。50 $\mathrm{ppm}$ 群の第 2 代の方が早期に起り, 重症である ことは世代による蓄積と考えられるが，この点は 歯牙の $\mathrm{F}$ 分析の項で考察されよう。

\section{6）硬組織フッ素分析}

成育した第 1 代仔（75日）と第 2 代仔(100日) のFレベル別分析值を表11，13に示した。また出 
表 11 第 1 代成育ラット（75 日）硬組織 F 量 ppm

\begin{tabular}{|c|c|c|c|c|c|c|c|}
\hline \multirow{2}{*}{$\begin{array}{c}F \text { レベル } \\
\text { ppm }\end{array}$} & \multirow{2}{*}{$\begin{array}{l}\text { 動 } \\
\text { 物 } \\
N a \\
N a\end{array}$} & \multicolumn{2}{|l|}{ 雄 } & \multirow{2}{*}{$\begin{array}{l}\text { 動 } \\
\text { 物 } \\
N a\end{array}$} & \multicolumn{3}{|c|}{ 雃 } \\
\hline & & 大腿骨 & 菌 牙 & & 䫘 & 大腿骨 & 㐘 牙 \\
\hline \multirow{6}{*}{0} & 1 & 186 & 165 & 1 & 14.1 & 186 & 11.0 \\
\hline & 2 & 12.0 & 13.0 & 2 & 13.3 & 22.2 & 125 \\
\hline & 3 & 126 & 18.0 & 3 & 12.4 & 24.0 & 185 \\
\hline & 4 & 12.0 & 12.5 & & & & \\
\hline & 5 & 156 & 15.5 & & & & \\
\hline & 平均 & 14.1 & 151 & & 132 & 21.6 & 14.0 \\
\hline \multirow{6}{*}{0.5} & 1 & 30.0 & 22.7 & 1 & 324 & 38.0 & 381 \\
\hline & 2 & 34.8 & 226 & 2 & 31.2 & 32.8 & 24.3 \\
\hline & 3 & 30.0 & 23.7 & 3 & 31.0 & 39.2 & 32.5 \\
\hline & 4 & 42.6 & 30.8 & & & & \\
\hline & 5 & 357 & 251 & & & & \\
\hline & 平均 & 34.6 & 24.9 & & 31.5 & 366 & 31.6 \\
\hline \multirow{6}{*}{1.0} & 1 & 576 & 29.9 & 1 & 51.0 & 64.2 & 59.1 \\
\hline & 2 & 40.9 & 331 & 2 & 50.0 & 50.0 & 40.4 \\
\hline & 3 & 45.0 & 322 & 3 & 484 & 34.9 & 391 \\
\hline & 4 & 551 & 336 & & & & \\
\hline & 5 & 45.8 & 35.0 & & & & \\
\hline & 平均 & 488 & 327 & & 49.8 & 49.7 & 462 \\
\hline \multirow{6}{*}{10} & 1 & 611 & 200 & 1 & 523 & 518 & 245 \\
\hline & 2 & 447 & 199 & 2 & 420 & 350 & 229 \\
\hline & 3 & 455 & 220 & 3 & 424 & 475 & 216 \\
\hline & 4 & 359 & 235 & & & & \\
\hline & 5 & 277 & 148 & & & & \\
\hline & 平均 & 429 & 200 & & 459 & 447 & 230 \\
\hline \multirow{6}{*}{50} & 1 & 1846 & 943 & 1 & 2788 & 2290 & 1073 \\
\hline & 2 & 2744 & 1526 & 2 & 2132 & 2640 & 1191 \\
\hline & 3 & 1876 & 1059 & 3 & 2054 & 2619 & 1082 \\
\hline & 4 & 1545 & 974 & & & & \\
\hline & 5 & 1386 & 1109 & & & & \\
\hline & 平均 & 1879 & 1122 & & 2324 & 2516 & 1115 \\
\hline
\end{tabular}

産後 3 週で離乳した親と, 離乳した仔との間の胎 盤, 乳汁を介してのF移行を知ろうとして, 市販 固形飼料(表 9 ) 低 F 飼育の親と第 1 代仔 (表 10 ), 第 1 代親と第 2 代仔(表12)，第 2 代親と第 3 代仔 (表14)の 4 組の親仔について, 離乳時に殺して, 硬組織を分析比較した。

\section{a) 市販固型飼料群（表 9)}

すでに述べたように市販オリエンタル固形飼料 は，魚粉を混入しているので，これに原因する天 然 $\mathrm{F}$ が極めて高く約 $45 \mathrm{ppm}$ に達する。食物を介 するF吸収は，飲用より劣るといわれるが，骨に は400 500ppm（乾燥重量当り）歯にはその $1 / 2$ 程度が含有されている。離乳仔の骨は5.9\% 6.3 $\%$, 歯は $11.3 \%$ 程度の低濃度で胎盤, 乳腺におけ る $\mathrm{F}$ 抑制を示している。

b) 第 1 代成育仔の硬組織 $F$ 濃度（表11）

第 1 代の仔の離乳仔(表10) 大腿骨平均 F は8.5 $\mathrm{ppm}$ ，歯牙6.2ppm（9例平均）であつたが，75日 低 $\mathrm{F}$ 基䃈飼料 (F 0.45ppm) で飼育すると雄は大腿 骨 14.1 , 歯牙 $15.1 \mathrm{ppm}$ ( 5 例平均) と有意の差を似 て増加している。これは基礎飼料中の微量の Fが 硬組織に蓄積して行ったためである。しかし此の 硬組織レベルは，市販固形飼料飼育成育ラット群 の硬組織 Fレベルのそれぞれ $3 \%$ および $9 \%$ に低 下している。 F 投与群は $0.5,1,10,50 \mathrm{ppm}$ 群 と硬組織 $\mathrm{F}$ 濃度は有意の 差をもつて 増加してい る。

雌は例数が不足なので, ここでは雄についてだ け論じると, 各群の平均值から基礎飼料からの F のとり込み，すなわち $0 \mathrm{ppm}$ 群の 基礎飼料によ る蓄積14.1および15.1を差引くと，各レベル純増 加 $\mathrm{F}$ 濃度の比は次のよ5になる。( $1 \mathrm{ppm}$ 基準)

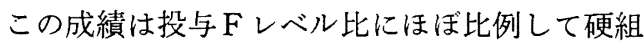
織 $\mathrm{F}$ 濃度が増加することを示している。ただ 50 
表 12 雐乳時ラット硬組織 $\mathrm{F}$ 量

c）低 $F$ 飼奇親仔の比較

\begin{tabular}{|c|c|c|c|c|c|c|}
\hline \multirow{2}{*}{$\begin{array}{l}\text { Fレベル } \\
\text { ppm }\end{array}$} & \multicolumn{3}{|c|}{ 離乳親（第 1 代） } & \multicolumn{3}{|c|}{ 離乳仔（第 2 代） } \\
\hline & 顎 骨 & 大腿骨 & 菌牙 & 頻骨 & 大腿骨 & 荤 牙 \\
\hline \multirow{4}{*}{0} & 14.5 & 25.2 & 19 & 10.2 & 本文参照 & 本文参照 \\
\hline & 14.5 & 13.8 & 11.5 & 7. 7 & & \\
\hline & 36.7 & 29.4 & 16.5 & 9.4 & & \\
\hline & 21.5 & 234 & 19.5 & 7. 6 & & \\
\hline \multirow[t]{2}{*}{ 平均 } & 21.8 & 22.9 & 16.6 & $\overline{87}$ & & \\
\hline & 36.7 & 31.0 & 21.9 & 9.0 & "I & $" 1$ \\
\hline \multirow{4}{*}{0.5} & 49.7 & 58.9 & 36.6 & 7. 6 & & \\
\hline & 30.3 & 387 & 24.5 & 11. 8 & & \\
\hline & 41.2 & 432 & 29.2 & 9. 7 & & \\
\hline & & & & 7. 3 & & \\
\hline \multirow[t]{2}{*}{ 平均 } & 39.4 & 42.9 & 281 & $\overline{9.1}$ & & \\
\hline & 84.6 & 64.2 & 52.5 & 89 & & \\
\hline \multirow{4}{*}{ 1. 0} & 72.2 & 71.8 & 40.5 & 86 & & \\
\hline & 82.0 & 59.6 & 480 & 11.4 & & \\
\hline & 79.0 & 61.6 & 560 & 14.5 & & \\
\hline & & & & 12.6 & & \\
\hline \multirow[t]{3}{*}{ 平㚬 } & 79.5 & 64.3 & 49.3 & 11.2 & & \\
\hline & 770 & 546 & 336 & 560 & & \\
\hline & 635 & 529 & 346 & 57. 4 & & \\
\hline \multirow[t]{3}{*}{10} & 530 & 495 & 496 & 310 & & \\
\hline & 540 & 496 & 418 & 42.0 & & \\
\hline & & & & 59.7 & & \\
\hline \multirow[t]{3}{*}{ 平均 } & 619 & 517 & 399 & 49.2 & & \\
\hline & 3280 & 2951 & 2744 & 500 & 514 & 348 \\
\hline & 2768 & 3134 & 3086 & 247 & 292 & 183 \\
\hline \multirow[t]{3}{*}{50} & 2920 & 2862 & 2058 & 572 & 547 & 349 \\
\hline & & & & 566 & 522 & 212 \\
\hline & & & & 600 & 557 & 422 \\
\hline 平均 & 2989 & 2982 & 2629 & 497 & 486 & 303 \\
\hline
\end{tabular}

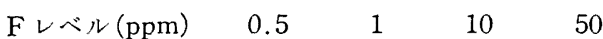

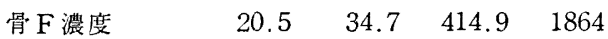

$\begin{array}{llllr}\text { 同上比 } & 0.6 & 1 & 12 & 64\end{array}$

$\begin{array}{lllll}\text { 歯 F 濃度 } & 9.8 & 17.6 & 184.9 & 1107\end{array}$

同上比 $\quad 0.56 \quad 1 \quad 10.5 \quad 63$

ppm レベルでは組織 F 増加率の方がやや大きい。

c）第 2 代成育仔の硬組織 $\mathrm{F}$ 䟴度（表13）

低 $\mathrm{F}$ 飼育第 2 代の仔は離乳時は，顎骨8.7ppm 程度であつた。大腿骨，歯牙については前述した ように分析值を棄却した。

この仔を基礎飼料中の $\mathrm{F}$ を蓄積した生後 110 日 目では大腿骨 12.9 ，歯牙 $10.6 \mathrm{ppm}$ に達した。

この骨と歯の F 濃度は第 1 代成育仔と有意差は ない。即ち著者の基礎飼料程度の低 F では，離乳 後に飼料から入る $\mathrm{F}$ 量が多く，世代を重ねても体 内 $\mathrm{F}$ 䟴度低下には役立たないことが明かとなつ た。 F 投与群は，投与レベルに比例して硬組織 $F$ 濃度が有意の差を似て増加をしていることは第 1 代と同傾向であるが，0.5，1 ppm の低濃度群で
は 第 2 代の歯牙 $\mathrm{F}$ は第 1 代のそれより低く, F 高濃度群 $(10,50 \mathrm{ppm})$ ではこの関係が見られな い印象を受ける。しかし，はたして有意の差であ るかの検定結果は後述の成績一覧表の項(表15)に 培る。

フィシュミール群は天然フッ素添加の意味で追 加したが，実測值， 飼料中20ppm であるのにか かわらず，硬組織 F 濃度は飲用 $10 \mathrm{ppm}$ 群よりは るかに低かつた。飲水量は飼料摂取量の 2 倍であ るとして捸取 F量を等しくしたつもりであるが， 蓄積率 (利用率) は食物経由の方が劣つた。

d）離乳仔の硬組織 $\mathrm{F}$ 濃度と親仔の関係

市販固形飼料（F約 $45 \mathrm{ppm}$ ) で飼育しても離乳 仔の組織 $F$ 濃度は著しく低いことは，すでに(a) 項で述べた。

固形飼料から低 $\mathrm{F}$ 飼料に変更して 2 ケ月後の離 乳親は表10に示すように，すでに硬組織 F 濃度は 骨で60\%，歯で27\%に低下していた。この親から 
表 13 第 2 代成育ラット (90日) 硬組織 $\mathrm{F}$ 量（ppm）

\begin{tabular}{|c|c|c|c|c|c|c|c|}
\hline $\begin{array}{r}F_{レ \sim ゚} \\
\text { ppm }\end{array}$ & $\begin{array}{l}\text { 動 } \\
\text { 物 } \\
\text { 的 }\end{array}$ & 大艆 骨 & 武 牙 & $\begin{array}{r}F_{レ \sim ゙} \\
\text { ppm }\end{array}$ & $\begin{array}{l}\text { 動 } \\
\text { 物 } \\
\text { Na }\end{array}$ & 大腿骨 & 牙 \\
\hline \multirow{6}{*}{0} & 1 & 134 & 158 & \multirow{6}{*}{10} & 1 & 678 & 254 \\
\hline & 2 & 127 & 10.5 & & 2 & 716 & 323 \\
\hline & 3 & 12.1 & 99 & & 3 & 433 & 179 \\
\hline & 4 & 14.6 & 9. 6 & & 4 & 769 & 281 \\
\hline & 5 & 11.8 & 20 & & 5 & 487 & 182 \\
\hline & 平均 & 129 & 10.6 & & 平均 & 617 & 244 \\
\hline \multirow{7}{*}{0.5} & 1 & 329 & 15.8 & \multirow{7}{*}{$\begin{array}{l}\text { フイシュ } \\
\text { ミール群 }\end{array}$} & 1 & 250 & 168 \\
\hline & 2 & 377 & 179 & & 2 & 391 & 161 \\
\hline & 3 & 373 & 19.1 & & 3 & 362 & 168 \\
\hline & 4 & 370 & 190 & & 4 & 421 & 219 \\
\hline & 5 & 25.0 & 14.5 & & 5 & 430 & 182 \\
\hline & & & & & 6 & 348 & 248 \\
\hline & 平均 & 362 & 173 & & 平均 & 367 & 191 \\
\hline \multirow{7}{*}{1} & 1 & 521 & 234 & \multirow{7}{*}{50} & 1 & 2960 & 1259 \\
\hline & 2 & 558 & 22.3 & & 2 & 2398 & 1317 \\
\hline & 3 & 51.8 & 22.5 & & 3 & 2600 & 977 \\
\hline & 4 & 40.7 & 229 & & 4 & 1988 & 1097 \\
\hline & 5 & 473 & 36.4 & & 5 & 2419 & 1234 \\
\hline & & & & & 6 & 2556 & 1059 \\
\hline & 平均 & 49.6 & 26.5 & & 平均 & 2487 & 1151 \\
\hline
\end{tabular}

離乳した仔の F 濃度は下顎骨 10.3 , 大腿骨 8.5 , 歯 牙 $6.2 \mathrm{ppm}$ でそれぞれ親の $3.7,3.3,11.5 \%$ に相 当する。

第 1 代（表12）

第 1 代の成育仔の離乳親とその離乳仔(第 2 代) とを前述したように常法に従い電気炉で灰化した ところ仔の硬組織はフッ素電極法では異常高值を 与え他の分析值 (非灰化, 酸溶解) と比較できな いから省略した。しかし非灰化法で分析した下顎 骨についてのみ論しれば，蒸留水群では親の $40 \%$ に低下し，8.7ppm の低值に達した。F 0.5ppm 投与群では，親の $23 \% ， 1 \mathrm{ppm}$ レベルでは，親 の $14 \%, 10 \mathrm{ppm}$ レベルでは $9.5 \%, 50 \mathrm{ppm}$ レベ ルでは $16.6 \%$ の低下率を示した。

幸いに歯のデータがある50ppm では親の歯に くらべ $11.5 \%$ に低下した。

第 2 代（表14）

第 2 代の仔の成育した離乳親とその離乳仔（第 3 代）の関倸は，親の下顎骨は 15 , 大腿骨 19 , 歯 牙 $8.4 \mathrm{ppm}$ と一見して第 1 代の親，仔より低い印 象を与えるが，後述するよ5に有意差検定では否 定され僅かに，第 1 代と第 2 代の親の大腿骨と歯 牙間それぞれ有意の差があつた。（表16）

親と仔の低下率は，颓骨 $50 \%$, 大腿骨 $49 \%$, 歯 牙 $94 \%$ で歯牙だけがほとんど親と不変な成績を得
た。この異常の現象は離乳親の歯の F 濃度が異常 に低かつたことに帰せられる。

$10 \mathrm{ppm}$ 投与群の親の測定值は第 1 代の $10 \mathrm{ppm}$ の親より有意差を似て高い。これは代を重社た蓄 積と考えられる。仔に関しては第 1 代 $10 \mathrm{ppm}$ で は下頡骨の分析值しかないが，これも高くなつて いる。

親仔の減少率は下䫟骨 $9 \%$, 大腿骨 $11 \%$ ，歯牙 $8 \%$ で，ほぼ10\%を中心とする減少率であつた。

\section{7）成育ラット硬組織 $\mathrm{F}$ 分析値一覧表と有意差} 検定

第 1 代と第 2 代の成育仔の分析値の平均值を表 15に示し, Wilcoxon ${ }^{25}$ の順位統計法による有意差 検定 $(\mathrm{P}<0.05)$ の結果を述べる。ただし雌は各群 3 匹の少数のため統計処理に不都合なので検定か ら除外し，雄についてだけ述べる。0 ppm群（低 $\mathrm{F}$ 基礎飼料）では骨と歯の濃度間に有意差がな い。第 1 代と第 2 代の骨, 歯それぞれの差も有意 でない。

0.5 と $1 \mathrm{ppm}$ 群では，第 1 代，第 2 代ともに骨 >歯また歯牙相互の比較では歯 (1) >歯 (2)……

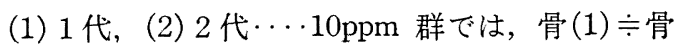
(2), 歯 (1) $\doteqdot$ 歯 (2) 50ppm 群では, 骨 (1)<骨 (2),

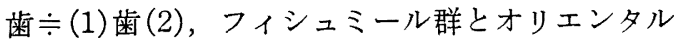


表 14 離乳時ラット硬組織 $\mathrm{F}$ 量

d) 低 $F$ 飼育の親你の比較 (第 2 代と第 3 代)

\begin{tabular}{|c|c|c|c|c|c|c|c|c|c|}
\hline & 動物 Na & 暍 & & 骨 & 大 & 腿 & 骨 & 霜 & 牙 \\
\hline \multirow{7}{*}{$\begin{array}{c}\text { 第 } \\
2 \\
\text { 代 } \\
\text { 離 } \\
\text { 乳 } \\
\text { 漞 }\end{array}$} & 1 & & 136 & & & 284 & & & 9. 3 \\
\hline & $2^{*}$ & ( & 161 & ) & ( & 360 & $0)$ & ( & $84)$ \\
\hline & 3 & & 133 & & & 176 & & & 6. 9 \\
\hline & 4 & & 1 4.2 & & & 15.4 & & & 6. 5 \\
\hline & 5 & & 19.2 & & & 176 & & & 0.6 \\
\hline & 6 & & 14.9 & & & 160 & & & 8.8 \\
\hline & 平均 & & 150 & & & 190 & & & 84 \\
\hline
\end{tabular}

* 非婎㜊

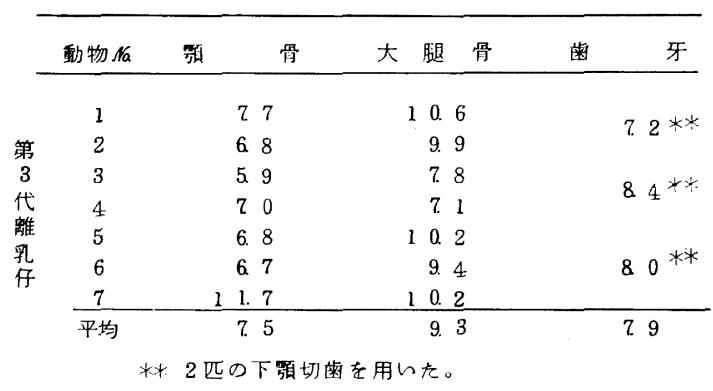

e ） F 10 ppm第 2 代と第 3 代の比較

\begin{tabular}{|c|c|c|c|c|c|c|c|c|c|c|}
\hline & 動物 16 . & 䫑 & & 骨 & 大 & 腿 & 骨 & 歯 & & 牙 \\
\hline \multirow{3}{*}{$\begin{array}{l}\text { 第離 } \\
2 \text { 乳 } \\
\text { 代親 }\end{array}$} & 1 & & 76 & 6 & & 71 & 3 & 36 & 61 & \\
\hline & 2 & & 81 & 5 & & 70 & 1 & 36 & 66 & 6 \\
\hline & 3 & & 80 & 6 & & 61 & 7 & 3 & 85 & 5 \\
\hline \multirow{4}{*}{$\begin{array}{l}\text { F10 } \\
\text { ppm }\end{array}$} & 4 & & 96 & 0 & & 83 & 8 & 3 & 4 & 4 \\
\hline & 5 & & 88 & 8 & & 97 & 2 & 7 & 5 & 0 \\
\hline & 6 & 1 & 18 & 3 & & 70 & 2 & 8 & 0 & 0 \\
\hline & 平均 & & 89 & 8 & & 75 & 7 & 5 & 0 & 1 \\
\hline
\end{tabular}

\begin{tabular}{|c|c|c|c|c|c|c|c|}
\hline & 動物任 & 䫑 & 骨 & 大 & 腿 & 骨 & 蔽 \\
\hline 第離 & 1 & & 87 & & 62 & & \multirow{2}{*}{$42.8^{\text {米标 }}$} \\
\hline 3 孚 & 2 & & 72 & & 71 & & \\
\hline 代仔 & 3 & 1 & 01 & & 68 & & \multirow{2}{*}{$35.2^{* 4}$} \\
\hline & 4 & & 84 & & 93 & & \\
\hline$F 10$ & 5 & & 66 & & 100 & & \multirow{3}{*}{351 * } \\
\hline ppm & 6 & & 87 & & 84 & & \\
\hline & 7 & & 77 & & 85 & & \\
\hline & 平均 & & 2. 1 & & 81.0 & & 377 \\
\hline
\end{tabular}

固形飼料群(表 9 )の間に骨も歯も有意差がない。

8）離乳親と離乳仔の硬組織 F 分析値一覧表と 有意差（表16）

本表は複雑であるので誤差検定を行つて有意差 のないもの相互間にだけ共通符号を附けた。その 他の数值間には有意差があることになるが，下頑 骨と大腿骨の F 濃度は直観的にも知られるように 有意差はないが，複雑となるので表16では符号を
つけていない。有意差のないものを特別に記載す れば，低 $F$ 飼育 $(0 \mathrm{ppm}$ 群) の親の下顎骨 1 代と 2 代, 離乳仔の下䅡骨については低F 2 ケ月の親 の仔第 1 代 $0,0.5,1 \mathrm{ppm}$ 群と第 2 代の $0 \mathrm{ppm}$ 群 に有意差がない。大腿骨も同一傾向にあるが, 分 析法の失敗のため第 1 代仔のデータが不足してい る。

第 2 代の離乳親の歯牙 $\mathrm{F}$ 濃度が前述のように異 
表 15 成育ラット硬組織 $\mathrm{F}$ 沈着量平均值一筧表

\begin{tabular}{|c|c|c|c|c|c|c|c|}
\hline \multirow{2}{*}{$\begin{array}{c}F \cup へ ゙ \\
\text { ppm }\end{array}$} & \multicolumn{2}{|r|}{ 第 } & \multicolumn{2}{|c|}{ 代 } & \multirow[b]{2}{*}{ 歯 牙 } & \multicolumn{2}{|c|}{ 第 2 代 } \\
\hline & 大艇 骨 & 橧 牙 & 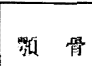 & $\begin{array}{c}\text { 古 } \\
\text { 大腿骨 }\end{array}$ & & 大腿骨 & 菌 牙 \\
\hline 0 & 14.1 & 151 & 13.2 & 21.6 & 14.0 & 12.9 & 10.6 \\
\hline 0.5 & 34.6 & 24.9 & 31.5 & 366 & 31.6 & 362 & 17. 3 \\
\hline 1.0 & 488 & 32.7 & 49.8 & 4.9.7 & 462 & 49. 6 & 265 \\
\hline 10 & 42.9 & 200 & 459 & 447 & 230 & 617 & 244 \\
\hline 50 & 1879 & 1122 & 2324 & 2516 & 1115 & 2487 & 1151 \\
\hline 冬侻 & & & & & & 367 & 191 \\
\hline
\end{tabular}

表 16 離乳親と離乳仔の $\mathrm{F}$ 沈着量一覧表

\begin{tabular}{|c|c|c|c|c|c|c|c|c|c|c|}
\hline \multirow{2}{*}{ 世代 } & \multirow{2}{*}{ 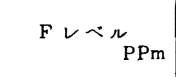 } & \multicolumn{3}{|c|}{ 下 暍 骨 } & \multicolumn{3}{|c|}{ 大 腿 骨 } & \multicolumn{2}{|l|}{ 宷 } & 牙 \\
\hline & & 親 & 仔 & $\%$ & 漞 & 仔 & $\%$ & 親 & 仔 & $\%$ \\
\hline \multirow{2}{*}{ 親 } & オリエンタル & 483 & 284 & 59 & 450 & 282 & 63 & 209 & 189 & 9 \\
\hline & $\begin{array}{c}\text { 低 } \mathrm{F} \text { 飼料 } \\
(2 \text { 月 })\end{array}$ & 288 & $10.3^{+}$ & 36 & 261 & $85^{\circ}$ & 33 & 45 & 62 & 14 \\
\hline \multirow{5}{*}{ 第 1 代 } & 0 & $21 . \stackrel{\times}{8}$ & & 40 & 22.9 & & & 16.6 & & \\
\hline & 0.5 & 39.4 & $9.1^{+}$ & 23 & 42.9 & & & 281 & & \\
\hline & 1.0 & 79.5 & $11.2^{+}$ & 14 & 64.3 & & & 49.3 & & \\
\hline & 10 & 61.9 & 4.9 .2 & 8 & 517 & & & 399 & & \\
\hline & 50 & 2989 & 497 & 17 & 2982 & 486 & 16 & 2629 & 303 & 12 \\
\hline \multirow{2}{*}{ 第 2 代 } & 0 & $150^{\times}$ & $7.5^{+}$ & 50 & 19.0 & $9.3^{\circ}$ & 49 & 84 & 7.9 & 94 \\
\hline & 10 & 898 & 82.1 & 9 & 757 & 81 & 11 & 501 & 37.7 & 8 \\
\hline 注： & \multicolumn{4}{|c|}{$\begin{array}{l}4 \sim 6 \text { 匹の平均值 } \\
5 \sim 7 \pi の \text { 平为值 }\end{array}$} & F p pm & ( 乾煤 & 喿重最 & & & \\
\hline
\end{tabular}


常に低かつたので (8.4 ppm)，第 3 代離乳仔の歯 $7.9 \mathrm{ppm}$ との間に有意差なく，第 1 代の $0 \mathrm{ppm}$ 親 $(16.6 \mathrm{ppm})$ の歯とは有意の差があつた。

\section{考察}

\section{1）フッ素分析法}

本実験において試料の F 分析には最近, 開発さ れた米国 Orion 社製のイオンメーター (Model 404)によるフッ素電極法を用いた。F電極法はと

くにF含量の少いしかも微量試料の分析 (50ppm 以下，3 20mg）に適している。従来法とくらべ て測定值の変動が少く, しかも多量の試料を短時 間で定量できる利点をもち，1 日30試料は十分に 分析可能である, Gr $\phi \mathrm{n}$, Brudevold $^{23)}$ らは本法に より唾液中の F を定量しているが，本法は現在 F 定量法の主流となりつつある。

しかし，このF電極法にも，多少の疑問点があ る。Armstrong ${ }^{21)} ら$ は, 試料の $\mathrm{F}$ 含量が少い時, 定量值が低めにでるため, $\mathrm{Ca}$ と $\mathrm{Mg}$ を標準溶液 に添加することを推奨している。本実験でも低 $\mathrm{F}$ 濃度の試料, とくに離乳仔の 灰化処理した試料 は，乾燥試料（非灰化）の分析值に比べて成育ラ ットで10 20\%増, 離乳仔で約 5 倍の異常高值を 示したため、データとして利用できなかつた。こ の原因が，試料の有機質の含量と関係があるのか 否かを現在追求中であるが, 当教室の近藤の実験 によれば，ある程度までの $\mathrm{Ca}$ と $\mathrm{Mg}$ 共存は， 大きな測定誤差を来さないという。

試料の前処理において, 強酸抽出のみでは, $F$ が解離しにくい組織では, 灰化法やその他, 酸素 フラスコによる熱分解法と微量拡散法との併用に よる分析が必要とされるのでないかと考えられる が,このことについては, 現在, 当教室で検討中 である。

2) 血液所見 $(\mathrm{Ht}$ 值, 赤血球, 白血球, $\mathrm{Hb}$ 量, ALP, GOT),

生体に摂取された F が血液に与える影響につい て Leon $^{27)}$ らは高F 給水地区 ( 8 ppm)の Bartlett 116名と対照地区 (0.4ppm) Cameron 地区121名 について10年間以上検査地区に居住しているもの を選んで調査を行った。
その結果は，好中球の異常者の比率がやや高か つた程度で, 問題にするほどの差はなかつたと報 告している。副島 ${ }^{28)} ら は$ 高F地区桜島 $(0.40 \sim$ $0.96 \mathrm{ppm})$ と対照地区吉野 (0.05ppm 以下) の調 査結果では, 有意の差を認めないが, 赤血球数, 血色素量值が高 $\mathrm{F}$ 地区において低く, 阿蘇地区 (0.82 3.30ppm) との比較においては, 赤血球 数, 血色素量は少なく, 網状赤血球, 白血球数が 増加していると報告している。さらに家鬼による 動物実験では，1日 F 5.478mg を耳静脈より注 射して100 160日間観察し，白血球の減少を認め た程度と報告している。

著者の実験でも, $\mathrm{Ht}$ 值, 赤血球 白血球数, $\mathrm{Hb}$ 量は正常值の範囲であり，Fによる影響を見 いだすことはできなかつた。

アルカリフォスファターゼ(ALP), トランスア ミナーゼ(GOT)

Robinson $^{291}$ が骨成長における化骨部には ALP が，多量に存在していることをとりあげ，その後 Philips $^{30)}$ がF中毒症における ALP の増加を報告 して以来, 多数の報告がある。

低 $\mathrm{F}$ 飼育のラットの実験では, Maurer ら² (0.007ppm の基礎飼料) は, ALP 活性に有意の 差がないとしており, Maplesden ${ }^{8)} ら(3 \mathrm{ppm} の$ 基 礎飼料）も，ALP 活性には変化がないとしてい る。ごく最近の Doberenz ${ }^{6)}$ らの実験では低 F 飼 育ラット（基礎飼料中 $\mathrm{F}<0.005 \mathrm{ppm}$ ) 群と飼料に $2 \mathrm{ppm}$ を添加した群，さらに対照として飲料水 にF帛2.67ppm を添加した 3 群の間には, ALP, GOT とも有意差がなかつたと報告している。

本実験では, ALPは成長に従つて漸減した が，1 ppm 群が僅かに低值を示している程度で 各群の間には同様に有意の差を見出せなかつた。 マグネシウムの関与している多くの酵素は，とく に燐酸の存在下でフッ化物阻害を受けやすい。し かし酵素の感受性の相違によつて，フッ化物阻害 についてある法則性を見いだすことはむずかしい ようである。例えば，マグネシウムと関係の哚い Polynucleotide phosphorylase はフッ化物に対し て，全く感受性がないといわれる。Robinson ${ }^{31)} ら$ はその後(1953), in vitro の石灰化実験で $10^{-4} \mathrm{M}$ 
のFが石灰化障害を起し得るにもかかわらずここ の程度の濃度のFは，ALP の作用に影響を与え ないことを知って, ALP 以外の酵素が石灰化に 関していることを予想し石灰化の second mechanism が存在することを主張している。

\section{3）低フッ素飼料について}

1933年に Sharpless ${ }^{11} ら か ゙$ 低フッ素飼料を試作 したが，現在の低F 飼料のレベルからすれば十分 でなかった。その後 Phillips ${ }^{3)}$ (1934 1939) らは $0.1 \sim 0.2 \mathrm{ppm} の$ 低F飼料を調整し, Muhler ${ }^{4)}$ (1954) が0.1ppm, Maurer ${ }^{2)}$ (1957) らは, 0.007 ppm 以下, 飯塚 ${ }^{12)}(1964)$ は0.6ppm, Doberenz ${ }^{6)}$ (1964) らは0.005ppm 程度の低F 飼料による実験 成績を報告している。

低 F 飼育でラットのF 要求を分析した Venkateswarler ${ }^{32)}$ の成績によれば，低F 飼育の 2 群と 蒸留水飲用による対照群および F 10ppm 投与群 について，出産率を検べてみると，低F群に減少 があり， 3 代以後の繁殖が失敗に終わつたとい う。その原因として飼料の調整法や保存法に問題 があり，いわゆる人工飼料からある有毒性な因子 が影響した結果ではないかと推察している。

Muhler は低F飼料（0.001 ppm 以下）によつ てラットによる実験を試みたが, 累代繁殖が得ら れず観察ができなかつたという。

Maurer" ${ }^{2}$ らの低F実験によれば，Fによる影響 は歯のう蝕抑制効果以外には特異な知見を認めら れず，栄養学的にも non-essential ではないかと 結論している。

このようにラットの低 $\mathrm{F}$ 飼育実験による現在ま での成績には，満足な結論が得られていない。そ の原因の 1 つとして, 従来の定量法では，0.1ppm 以下の飼料中 F 測定に難点があつたのではない かと考える。その論拠として，このような低 $\mathrm{F}$ 飼 育にかかわらず，彼等の動物の硬組織には相当な Fが蓄積している。

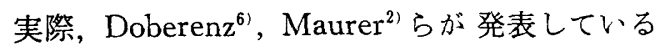
$0.005,0.007 \mathrm{ppm}$ 以下の低 $\mathrm{F}$ 飼料を作製するこ とは, 飼料の組成分から検討してみて, かなりの 困難を伴う。著者は本実験に拉いて，0.45ppm の低 $\mathrm{F}$ 飼料を調整し得たがドライミルク，カゼイ
ン，塩類成分の一部から，さらに除フッ素を完 全に行えば， $0.1 \mathrm{ppm}$ 前後の低 F 飼料をつくり得 るのではないかと検討している。

\section{4）低 $\mathrm{F}$ 飼育動物の硬組織 $\mathrm{F}$ 濃度}

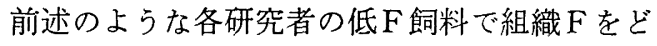
の程度まで低下し得たかの比較はやや困難があ る。第 1 に研究年代の差で分析法の精度が問題と なり，ことに飼料中の公表 $\mathrm{F}$ 濃度には信頼性が少 い。次にラットの測定時の日令が不一致で精確な 比較に適しない。しかし極力近似する条件のもの を選ぶと下表の如くなる。

\begin{tabular}{|c|c|c|c|}
\hline & \multirow{2}{*}{$\begin{array}{l}\text { 飼料 F } \\
((\text { ppm }\end{array}$} & \multicolumn{2}{|c|}{ 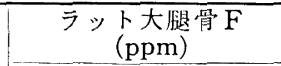 } \\
\hline & & 雕乳仔 & 成育仔 \\
\hline $\begin{array}{l}\text { Evans and Phillips } \\
(1939)^{3)}\end{array}$ & $0.1(?)$ & $\begin{array}{l}3.5 \sim \\
5.7\end{array}$ & $\begin{array}{c}8 \sim 16 \\
(120 \text { 日以上) }\end{array}$ \\
\hline Muhler $(1954)^{4)}$ & 0.1 & & $23 \sim 29$ (90日) \\
\hline $\begin{array}{c}\text { Maurer et al } \\
(1957)^{2)}\end{array}$ & 0.007 & & $\begin{array}{c}1.2 \sim 2.7 \\
(105 \sim 325 \text { 日) } \\
\text { (灰分より換算) }\end{array}$ \\
\hline Doblenz $(1964)^{6)}$ & $<0.005$ & & $2.92(90$ 日) \\
\hline 飯塚 (1964) 12) & 0.6 & & 22 (90日) \\
\hline 鈴木 (1969) & 0.45 & $7 \sim 9$ & $\begin{array}{c}13 \sim 14 \\
(90 \sim 100 \text { 日 })\end{array}$ \\
\hline
\end{tabular}

著者の飼料の除 $\mathrm{F}$ 度は, 米国の研究者らには及 ばないが，ラット硬組織 $\mathrm{F}$ 蓄積量からみると Maurer $^{2)}$, Doblenz ${ }^{6)}$ の超低Fを除けば, 他の研 究者とは同程度に達している。しかも Maurer, Doblenz らは笑験群の設定が少く, 後者はこと に動物数が少い。

\section{5）フッ素の胎盤乳腺移行}

フッ素の胎盤移行については多くの研究があ る。Muhler の母犬にF 0，1，3，5，10，25，50 $\mathrm{ppm}$ の飲料水を飲ました実験によると, 生後1, 10，30日の仔の体内 $\mathrm{F}$ 量は $5 \mathrm{ppm}$ まで差がなく， $10 \mathrm{ppm}$ で僅かに増え，25，50ppm 群では，0ppm に比して $2 \sim 3$ 倍の F 量があつたという。この結 果は Knouff ${ }^{33 !}$ のデータと一致している。

ラットを用いた実験については, 多くの研究が なされているが，現在，飲水料中8 10ppm F でのFは胎盤の抑制をうけ，胎仔に移行しない が，このレベル以上だと非生理的に胎仔に移行す るといわれている。

Murray $^{34)}$ は F 500ppm の飲料水群と対照群の 
母体の胎仔はそれぞれ5.1と $1.1 \mathrm{ppm}$ であり，F はまた母乳を通して仔に移行すると結論した。

著者の実験では胎仔の分析をしていないが（現 在，F電極法で定量することを検討中である)， F $0,0.5,1 \mathrm{ppm}$ の離乳仔は各群の間に有意差は ないが，10ppm の離乳仔は明らかな有意の増加 がみられた。これは先人の研究者の限界濃度と一 致したが彼らは新生仔についての所見であり，著 者のは, 生後 3 週の離乳仔についての分析值であ る点で異つている。したがつて著者の場合は胎盤 通過だけでなく, 母乳からの捸取, 即ち乳腺の生 理的障壁機能が併せ考慮していることになる。し かし著者の実験は $1 \mathrm{ppm}$ レベルの次に10ppm レ ベルに跳んでいるので，この中間の如何なる濃度 （例えば $5 \mathrm{ppm}$ か $8 \mathrm{ppm}$ か）が限界点かについて は情報を呈供することができない。

しかし F の胎盤移行度は動物の種差に従つて大 差があり，ラットの成績を直ちに人体に適用はで きない。最近は胎盤の解剖的構造から，モルモッ トが最もヒトに似るとして，モルモットによる胎 盤移行が研究されているが (Muhler) ${ }^{7}$ 著者の研究 と比較することは数值のオーダーが異るため困難 であるので引用しない。

\section{総括}

フッ素は栄養的に必須ミネラルであろうかとい ら疑問に対する解答，および親から仔への移行， すなわち胎盤，乳腺のフッ素に対する生理的障壁 機能の程度を知るために累代低フッ素飼育実験を 企画した。同時にこれに 4 段階のフッ素濃度の飲 料水を与え, 平行的に観察した。

1）小麦粉，カゼイン，ドライミルクおよび精 製塩類を主成分とする低 F 基礎飼料 (F 0.45ppm) をつくつた。

2）フッ素定量には最新のFイオン電極法を採 用し, $\mathrm{F}$ 含量の少い硬組織の前処理は過クロール 酸溶解法を用いた。

3) Sprague-Dawley 采ラットを 2 ケ月上記の 低 $\mathrm{F}$ 飼料で飼育し，その仔に 0 (蒸留水)，0.5, $1,10 お$ よび $50 \mathrm{ppm}$ のF 飲料水を, 自由に与え, 各群の体重増加, 血液所見, 酵素活性および硬組
織 $\mathrm{F}$ 濃度を第 2 代まで追求し，第 3 代では 0 およ び10ppm 群のみ実験した。

4) 体重増加は F 50ppm で雌雄とも，F 10 $\mathrm{ppm}$ で第 2 代の雄にのみ抑制がみられた。

5）眼窩静脈叢採血および心臟穿刺血による血 球数, アルカリフォスファターゼ, GOT 検査は 投与 $F$ レベル間に有意の差を示さなかつた。

6) 歯牙フッ素症は，世代を重㸚る程出現時期 が早まり，親からのフッ素移行を示唆した。

7）第 1 代成育仔 0 ppm の大腿骨は F 14.1, 切歯は15.1ppm で，市販固形飼料飼育ラットの それぞれ $3 \%$ および，9\%に低下した。

8）第 2 代の低 $F$ 飼育成育仔の硬組織 $F$ 濃度は 第 1 代成育仔と有意差を示さなかつた。この原因 は著者の基礎飼料が理想的な低 $\mathrm{F}$ に達していない ので，発育の経過中に第 1 代，第 2 代とも飼料か らほぼ等量の Fをとり込むためである。

9）第 1 代の離乳親とその離乳仔（第 2 代）の 下顎骨の $\mathrm{F}$ 濃度の関係は, 仔は親の $40 \%(8.7 \mathrm{ppm})$ に低下した。歯牙間の比較は分析に技術上の難点 がありデータを提出できない。

10）第 2 代の離乳親とその離乳仔（第 3 代）の 下顎骨· F 濃度は $50 \%$ に低下（7.5ppm）したが切畨 は僅かに94\%に低下したに過ぎなかつた。これは 第 2 代離乳親の歯牙 $F$ 濃度が異常に低かつたこと に原因がある。

11）低 $\mathrm{F}$ 飼育の親の下䅡骨 1 代と 2 代の間, 離 乳仔の下顎骨第 1 代の F $0,0.5,1$ ppm 群の間 にそれぞれ有意差がない。

12） F 投与群の硬組織では，F $0.5 ， 1 ， 10,50$ $\mathrm{ppm}$ 群の間に有意の差を似て F 䟴度が増加する。 しかしその離乳仔では $0,0.5,1 \mathrm{ppm}$ レベルの間 に有意差がない。これは,この濃度まで山胎盤, 乳腺の生理的 barrier がよく働いて, 仔への蓄積 を一定レベルに抑えていると考えたい。

13) $10 \mathrm{ppm}$ 以上 $(1 \sim 10 \mathrm{ppm}$ の間は著者のデー タがない） $50 \mathrm{ppm}$ までは離乳仔の骨，歯の F 濃 度低下はほぼ親に対して $10 \%$ の定率を示すが， そのことは仔の濃度の絶対値は親の濃度に比例し て増加することを意味し，あたかも物理化学的沪 過を思わせる。 
14）フィシュミール 群（天然 F 20ppm）と 10 $\mathrm{ppm}$ 飲用群の比較は, 前者の硬組織 $\mathrm{F}$ 濃度の方 が有意に低かつた。硬組織を含まない魚肉中の F 利用率さえも，飲料水からのF吸収に劣ることを 確認した。

本研究に対して終始御指導を賜つた上田喜一教授に 深爵し，また貴重な助言と援助を惜しまれなかつた西村 正雄助教授, 高江洲義矩講師に感謝します。その他青木 講師, 近藤講師, 前橋講師をはじめ教室員諸氏の温い御 協力に謝意を表します。さらに低フッ素飼料の作成に関 して, 種々の助言を頂いた神奈川歯科大飯塚喜一教授に 深く感謝します。

本研究は第 17 回口腔衛生学会総会（昭和 43 年 7 月）に 発表した。

\section{参考文献}

1) Sharpless, G. R. and McCollum, E. V. : Is fluorine an indispensable element in the diet? J. Nutr., 6 : 163-178, 1933.

2) Maurer, R. L. and Day, H. G.: The nonessentiality of fluorine in nutrition. J. Nutr., 62 : 561-573, 1957.

3) Evans, R. J. and Phillips, P. H. : A new low fluorine diet and its effect upon the rat. J. Nutr., $18:$ 353-360, 1939.

4) Muhler, J. C. : Retension of fluorine in the skeleton of the rat receiving different levels of fluorine in the diet. J. Nutr. $58: 481,1954$.

5) Muhler, J. C. : Is fluorine a Dietary Essential? J. Am. Col. Den. 25 : 287-288, 1958.

6) Doberenz, A. R., Kurnick, A. A., Kurtz, E. B. and Reid, B. L. : Effect of a minimal fluoride diet on rats. Proc. Soc. Exp. Biol. and Med., $117: 689-693,1964$.

7) Hudson, J. T., Stooky, G. K. and Muhler, J. C. : The placental transfer of fluoride in the guinea pig. Archs oral Biol., 12:237246, 1967.

8) Maplesden, D. C., Motzok, I., Oliver. W. T. and Branion, H. D. : Placental transfer of fluorine to the fetus in rats and rabbits. J. Nutr., $71: 70-76,1960$.

9) Babeaux, W. L. and Zipkin, I. : Dental aspects of the prenatal administration of fluoride. J. Oral Therap. and Pharmacol., 3 : 124-135: 1966.

10) Anonymous: Prenatal exposure to fluoride. Nutrition Reviews, 25 : 330-332, 1967.

11）オリエンタル酵母工業株式会社 : オリエンタル 固型飼料. N. M.

12）飯塚喜一：フツ素に関する衛生学的研究, 第 3
編 飲料水および食物から摂取したフッ素の吸 収および蓄積について，歯科学報，64:726734, 1964.

13) McClendon. J. F. : A. method for producing fluoride-free salts and a fluoride-free diet. J. Dent. Res $38: 199,1959$.

14) Megregian, S. : Chemical analysis, Vol. III. Colorimetric Determination of Nonmetals. pp. 231-239, edited by Boetz D. F., New York 1958.

15）小山良修：動物実験手技，105-114，協同医書 出版, 1958.

16) Halpern, B. N., et: A.. Pacaud: Technique de prélèvement d'échantillons de sang. chez les petits animux de laboratoire par ponction du plexus optalmique. C. R. Soc. Biol., 145, 1465-1466, 1951.

17）飯塚喜一：フッ素に関する衛生学的研究, 第 1 編 フッ素の定量法に関する研究, 日本衛生学 雑誌, $18: 427-438,1964$.

18）高江洲義矩, 近藤武, 上田喜一 : 簡易水中フッ 素濃度測定法に関する研究 (学会抄録), 歯科学 報, $66: 484 ， 1967$ ，

19）高江洲義矩 : Alizarin Complexan によるフッ 素の微量および超微量定量法とその応用, 口腔 衛生学雑誌, $16: 1-20$.

20）近藤武，高江洲義矩：フッソ電極による喠液中 フッ素測定およびその臨床的応用 (学会抄録), 歯科学報, $69: 44,1969$.

21) Singer, L. and Armstrong, W. D. : Determination of fluoride in bone with the fluoride electrode. Anal. Chem., 40 : 613-614, 1968.

22) McCann, H. G. : Determination of fluoride in mineralized tissues using the fluoride ion electrode. Archs oral Biol., 13 : 475-477, 1968.

23) Gr $\phi$ n, P., McCann, H. G. and Brudevold, F.: The direct determination of fluoride in human saliva by a fluoride electrode. Fluoride levels in parotid saliva after ingestion of single doses of sodium fluoride. Archs oral Biol., 13 : 203-213, 1968.

24) Wabeke and Van Eeden: Handleiding voor de toets van Wilcoxon, Report S 176(M 65), Mathematisch Centrum, Statistische Afdeling, Amsterdam, 1955

Cited from Documenta Geigy Scientific Tables (6 th ed.) pp. 124-125, 191,

J. R. Geigy S. A., Basel, Switzerland. 1962.

25) (1) Wilcoxon, F. : Some rapid approximate statistical procedures. Ann. New York Accad. Sci. $52: 888-814,1950$.

(2) 高橋晄正：順序統計量を用いる簡単な差の 検定法, 化学の領域, 増刊, $36: 11-26$, 南江 堂, 1959 . 
26）上田喜一ほか：日本の斑状歯クラフ，歯界展望 $31: 7,1968$.

27) Leone, N. C., Shimkin, M. B., Arnold, F. A., Stevenson, C. A., Zimmerman, E. R., Geiser, P. A. and Lieberman, S. E. : Medical Aspects of Excessive Fluoride in a Water Supply. Pub. Health Rep. 69 : 925-936, 1954.

28）副島㑆二: 慢性弗素中毒症に関する研究, 日本 口腔科学会誌, $6: 1-29,1957$.

29) Robinson, R. and Soames, K. M. : The possible significance of hexosephosphoric esters in ossification Biochem. J. 18 $(3,4) 740$ 754, 1924.

30) Phillips, P. H., Star, F. J. : A study of respiration and certain reducing substances in chronic fluorosis and scurvy in the guinea pig J. Biol. Chem: 106: 41, 1934.

31) Robinson, R., and Rosenheim, A.H. : Calcification of hypertrophic cartilage in vitro. J. Biol. Chem. $161: 53,1953$.

32) Fluoride and Human Health, Vol. II. pp. VI. 25-26, WHO. Geneva. 1967 より引用.

33) Knouff, R. A., Edwards, L. F., Preston, D. W. and Kitchen, P. C.: Permeability of placenta ot fluoride. J. Dent. Res. 15, 291294, 1936.

34) Murray, M. M. : Maternal. transference of fluorine J. Physiol, $87:$ 388-393, 1936.

35) Hadjimarkos, D. M. : Dietary fluoride and fluorosis in Thailand. Amer. J. Pub. Hlth., 56 : 391-392, 1966. 